\title{
PENGARUH KEPEMIMPINAN KEPALA SEKOLAH DAN KOMPENSASI TERHADAP KEPUASAN KERJA GURU SMPN KOTA SEMARANG
}

\author{
Sudharto \\ IKIP PGRI Semarang (e-mail: yplpptpgrisemarang@gmail.com; \\ HP: 0811280652)
}

\begin{abstract}
The Contributions of Principals' Leadership and Compensation to the Job Satisfaction of State Junior High School Teachers in Semarang. The objective of the study is to investigate the contributions of principals' leadership and compensation to teachers' job satisfaction. The sample consisted of 288 teachers of state junior high schools in Semarang. The data were collected using a questionnaire and were analyzed using a regression technique. The results show that: (1) individually and aggregately, there are positive and significant contributions of principals' leadership and compensation to teachers' job satisfaction; and (2) $45.7 \%$ of teachers' job satisfaction is contributed by principals' leadership and $30.1 \%$ by compensation. It can be concluded that principals' leadership has a greater contribution than compensation to the improvement of the satisfaction of teachers of state junior high schools in Semarang.
\end{abstract}

Keywords: principals' leadership, compensation, teachers' job satisfaction

\section{PENDAHULUAN}

Kepemimpinan kepala sekolah memainkan peranan penting dalam upaya peningkatan kualitas kerja guru. Dalam proses belajar mengajar kepemimpinan adalah suatu bentuk kegiatan dalam kehidupan yang mengandung maksud mempengaruhi orang lain agar bersedia secara bersama-sama untuk menuju sesuatu yang telah ditentukan berdasarkan tujuan pendidikan.

Indrafachrudi \& Tahalele, (1995:7) berpendapat bahwa kepemimpinan adalah proses mengarahkan, membimbing, mempengaruhi, mengawasi pemikiran, perasaan atau tindakan dan tingkah laku orang lain. Kepemimpinan adalah tindakan atau perbuatan di antara per- seorangan dan kelompok yang menyebabkan orang, seorang maupun kelompok bergerak ke arah tujuan tertentu. Guru sebagai pelaksana pendidikan di sekolah yang berhubungan langsung dengan anak didik mempunyai peranan penting dalam peningkatan mutu pendidikan serta pencapaian tujuan pendidikan. Menurut Surya (2000:2), guru mempunyai makna sebagai seseorang yang mempunyai tugas dan tanggung jawab untuk mendidik dan mengembangkan kepribadian anak didik, baik yang berlangsung di sekolah maupun di luar sekolah. Kedudukan guru tidak dapat seluruhnya digantikan oleh alat, meski secanggih apa pun. Semakin akurat guru melaksanakan 
fungsinya, semakin terjamin tercipta dan terbina kualitas lembaga pendidikan/sekolah. Guru sebagai bagian dari organisasi sekolah, tentunya dalam mewujudkan tuntutan-tuntutan sebagaimana tersebut di atas, tidak terlepas dari peranan kepemimpinan kepala sekolah.

Selain faktor kepemimpinan, faktor kebutuhan, khususnya kesejahteraan guru juga akan memberi warna tersendiri pada kepuasan kerja guru. Menurut Maslow (1994:64), kebutuhan manusia dapat dibagi menjadi lima jenjang yaitu: (1) kebutuhan fisiologis; (2) kebutuhan keselamatan; (3) kebutuhan sosial; (4) kebutuhan akan harga diri; dan (5) kebutuhan pemenuhan diri. Pada dasarnya manusia itu akan termotivasi untuk melakukan sesuatu kegiatan apabila mempunyai harapan untuk terpenuhi kebutuhannya. Begitu juga seorang guru sebagai manusia biasa akan termotivasi untuk bekerja sebaik mungkin bila dia punya harapan akan terpenuhinya kebutuhan mereka.

Penelitian mengenai kepuasan kerja pernah dilakukan oleh para mahasiswa pascasarjana dari berbagai perguruan tinggi. Kasidi (2003) dalam tesisnya yang berjudul "Hubungan antara Kepuasan Kerja dengan Motivasi Kerja Ditinjau dari Jenis Kelamin pada Pegawai Dinas Pendapatan Daerah (DIPENDA) Kabupten Dati II Sukoharjo" menyimpulkan bahwa kepuasan kerja mempunyai hubungan signifikan dengan motivasi kerja. Sumadi (2006) dalam tesisnya yang berjudul "Hubungan Kepemimpinan, Lingkungan Kerja dengan Kepuasan Kerja pada SMA Negeri I Wonogiri“ juga menyimpulkan bahwa kepemimpinan dan lingkungan kerja berpengaruh positif terhadap kepuasan kerja. Supardi (1993) dalam tesisnya yang berjudul "Hubungan Kepemimpinan, Motivasi Kerja dan Lingkungan Kerja dengan Karier Jabatan Akademik Dosen PTS Kopertis Wilayah V DIY" menyimpulkan ternyata kepemimpinan, motivasi dan lingkungan kerja berpengaruh positif terhadap karier jabatan akademik dalam proses menajemen sumber daya manusia.

Penelitian tentang kepuasan kerja tersebut sasarannya adalah staf/pegawai DIPENDA, dosen, dan guru SMA. Variabel penyebab (independen) belum ada yang mengungkap dari aspek kompensasi. Karena itu, untuk melengkapi khasanah pengetahuan di atas, perlu dikembangkan lebih lanjut penelitian yang mengungkap kepuasan kerja untuk para guru SMP ditinjau dari aspek kepemimpinan kepala sekolah dan kompensasi yang diterima baik secara materi maupun nonmateri. Baik variabel kepemimpinan maupun kepuasan kerja dalam penelitian ini menggunakan landasan teori yang berbeda dan indikator yang berbeda dengan penelitian yang telah dilakukan oleh Kasidi, Sumadi, mau pun Supardi. Hal ini penting dilakukan karena selama ini yang menjadi sorotan rendahnya mutu pendidikan disebabkan oleh kinerja guru yang belum optimal. Kinerja guru yang belum optimal disebabkan karena kesejahteraan yang kurang memadai untuk dapat hidup layak setiap hari dari segi kompensasi. Penelitian ini dilakukan pada para guru SMP Negeri di Kota Semarang. Inilah yang melatarbelakangi perlunya dilakukan peneliti- 
an tentang kepuasan kerja guru ditinjau dari aspek kompensasi yang diterima dan kepemimpinan kepala sekolah. Penelitian ini diharapkan dapat ditemukan faktor dominan yang mempengaruhi kinerja guru.

Permasalahan yang diteliti dalam penelitian adalah: "Apakah kepemimpinan kepala sekolah dan kompensasi berpengaruh terhadap kepuasan kerja guru-guru SMP Negeri di Kota Semarang?

Tujuan yang ingin dicapai melalui penelitian ini adalah untuk mengetahui pengaruh kepemimpinan kepala sekolah dan kompensasi yang diterima para guru terhadap kepuasan kerja guruguru SMP Negeri di Kota Semarang.

Hasil dari penelitian diharapkan bermanfaat: (1) sebagai sumber informasi bagi pembinaan guru-guru SMP Negeri di Kota Semarang, guna pembenahan dan peningkatan sumber daya manusia terutama guru-guru negeri; (2) sebagai perbendaharaan pengetahuan tentang manajemen sumber daya manusia, khususnya mengenai bagaimana mengelola lingkungan organisasi sehingga dapat menciptakan kepuasan kerja; (3) sebagai bahan perbendaharaan perpustakaan pada instansi terkait untuk mengadakan penelitian selanjutnya; dan (4) sebagai bahan pertimbangan secara ilmiah dalam pengambilan kebijakan mengenai kepuasan kerja guru, khususnya di lingkungan Kota Semarang.

\section{METODE}

Penelitian ini menggunakan pendekatan ex post facto, yaitu menggali faktafakta yang peristiwanya telah terjadi dengan menggunakan angket berisi sejumlah pertanyaan yang merefleksikan persepsi responden terhadap kepemimpinan kepala sekolah, kompensasi, dan kinerja guru SMP Negeri di Kota Semarang. Robbins (1991:125) berpendapat, "Perception can be defined as a process by which individuals organize and interpret their sensory impressions in order to give meaning to their environment".

Demikian pula Gibson, J.L., Ivancevich, J.M., dan Donnelly, J.H. (1996) mengartikan persepsi sebagai proses pemberian arti atau makna terhadap lingkungan oleh individu. Proses persepsi meliputi kegiatan seleksi, penyusunan dan penafsiran terhadap suatu objek atau kejadian di sekitar kehidupannya yang didasari oleh pengetahuan, pengalaman, dan nilai yang dimiliki. Dalam proses pemberian makna terhadap lingkungannya, seseorang dapat menggunakan inderanya melalui proses mendengar, melihat, meraba, merasakan ataupun menggunakan indera penciuman.

Persepsi guru tentang kepemimpinan kepala sekolah merupakan suatu proses penafsiran, penilaian terhadap perilaku kepemimpinan kepala sekolah dalam menjalankan tugas kepemimpinannya, terutama dalam hubungan kerjasama dengan para guru. Persepsi guru tentang kompensasi berkaitan dengan interpretasi dan penafsiran guru berkaitan dengan imbalan yang diterima, baik dalam bentuk materi maupun nonmateri dari tempat dia bekerja.

Populasi penelitian ini adalah seluruh guru SMP Negeri di Kota Semarang sebanyak 1.438 guru, yang tersebar di 39 SMP Negeri. Mengingat 
jumlah populasi lebih dari 1000, besarnya sampel ditetapkan $20 \%$ sehingga diperoleh sampel $20 \% \times 1.438=287,6$ dibulatkan menjadi 288. Sampel diambilsecara proposional random sampling.

Instrumen penelitian berupa angket yang digunakan untuk mengumpulkan data terlebih dahulu diujicobakan terhadap 32 orang guru SMP berstatus PNS di luar sampel penelitian, untuk menguji validitas dan reliabilitas setiap butir (item) pertanyaan atau pernyataan. Uji validitas dan reliabilitas butir angket dilakukan dengan menggunakan komputer program SPSS versi 17. Jadi, instrumen yang digunakanuntuk mengumpulkan data adalah instrumen yang telah teruji validitas dan reliabilitasnya.

Contoh pernyataan angket.

Variabel Kepemimpinan kepala sekolah

> Saya merasa nyaman menjadi guru di SMP negeri tempat saya mengajar dengan gaya kepemimpinan yang diterapkan kepala sekolah.

Pimpinan saya mendorong guruguru untuk mengambil inisiatif dalam memecahkan persoalan.

Variabel Kompensasi

Apakah gaji yang Bapak/Ibu terima sesuai dengan beban tugas yang harus Bapak/Ibu lakukan?
> Apakah honor yang Bapak/Ibu terima di luar gaji/tunjangan, setelah melaksanakan tugas-tugas tambahan, di luar tugas pokok telah sesuai harapan?

Variabel Kepuasan Kerja

> Jenjang kenaikan kepangkatan dan golongan saya termasuk lancar.

$>$ Di ruang kerja guru cukup nyaman sehingga menjadikan betah tinggal di sekolah.

Uji hipotesis dilakukan dengan teknik regresi ganda. Karena itu, data yang terkumpul terlebih dahulu harus diuji normalitas, linieritas, homogenitas dan kolinieritasnya. Untuk menguji normalitas sebaran data digunakan "normal probability plot", uji homogenitas menggunakan grafik Standardized Scatterplot, uji kolinieritas menggunakan eigen-value, dan untuk uji linearitas data menggunakan Curve Estimation.

\section{HASIL}

Berdasarkan data yang diperoleh dari lapangan selanjutnya dianalisis dengan statistik deskriptif menggunakan komputer program SPSS versi 17 sebagai berikut.

Tabel 1. Hasil Analisis Descriptive Statistics

\begin{tabular}{|c|c|c|c|c|}
\hline & & Kepemim & Kompen & Kepuas \\
\hline \multirow[t]{2}{*}{$\mathrm{N}$} & Valid & 288 & 288 & 288 \\
\hline & Missing & 0 & 0 & 0 \\
\hline Mean & & 65.50 & 68.94 & 61.23 \\
\hline Std. Deviation & & 6.819 & 7.023 & 5.458 \\
\hline Range & & 29 & 32 & 23 \\
\hline Minimum & & 50 & 52 & 50 \\
\hline Maximum & & 79 & 84 & 73 \\
\hline Sum & & 18864 & 19854 & 17634 \\
\hline
\end{tabular}


Data hasil penelitian mengenai kepemimpinan kepala sekolah berdasarkan jawaban angket yang telah dikerjakan oleh para guru skor tertinggi 79 dan skor terendah 50 . Skor rata-rata $(X)$ kepemimpinan kepala sekolah 65,50; standar deviasi 6,819; range 29. Range digunakan untuk menentukan interval. Untuk memperoleh kepastian apakah baik atau tidak kepemimpinan kepala sekolah menggunakan skor hasil penelitian. Adapun rumus yang digunakan untuk menentukan interval adalah Range (skor tertinggi dikurangi skor terendah) dibagi 4 katogori, sehingga dapat disusun tabel frekuensi sebagai berikut.

\section{Tabel 2. Dekripsi Skor Hasil Penelitian Kepemimpinan Kepala Sekolah}

\begin{tabular}{cccl}
\hline Interval & Frekuensi & Persentase & Kategori \\
\hline $71-77$ & 70 & $24 \%$ & Sangat baik \\
$64-70$ & 103 & $36 \%$ & Baik \\
$57-63$ & 89 & $31 \%$ & Agak baik \\
$50-56$ & 26 & $9 \%$ & Kurang baik \\
\hline Jumlah & 288 & 100,00 & \\
\hline
\end{tabular}

Berdasarkan Tabel 2 di atas ternyata kepemimpinan kepala sekolah di SMP Negeri Kota Semarang pada kategori sangat baik $24 \%$ dan baik $36 \%$, sedangkan yang agak baik $31 \%$, dan kurang baik 9\%. Hasil analisis deskriptif mengenai kepemimpinan kepala sekolah dapat disajikan dalam bentuk grafik silinder sebagai berikut.

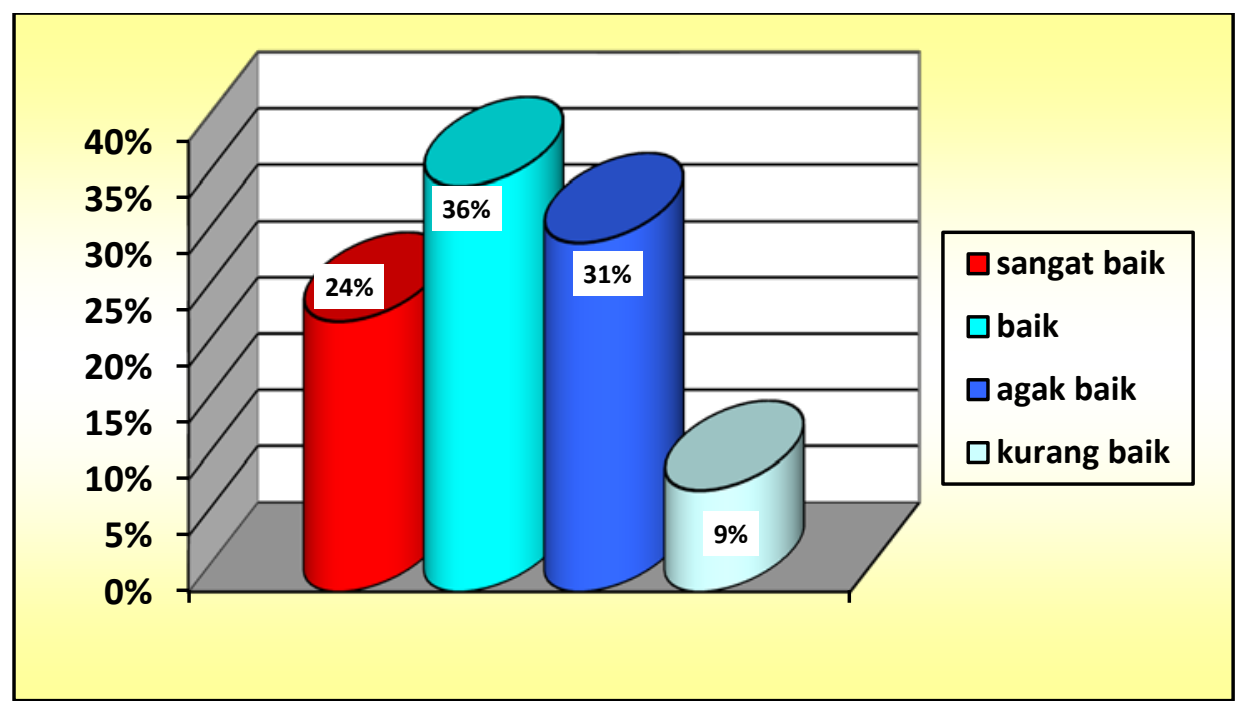

Gambar 1. Grafik Silinder mengenai Kepemimpinan Kepala Sekolah 
Mengenai kompensasi dari hasil penelitian (Tabel 1) diketahui nilai ratarata $(\mathrm{X})$ 68,94; standar diviasi (SD) 7,023; skor terendah adalah 52, skor tertinggi 84, dan range 32. Seperti telah disebutkan di atas bahwa Range digunakan untuk menentukan interval sebagai dasar untuk membuat tabel frekuensi bergolong, sehingga menghasilkan tabel sebagai berikut.

Tabel 3. Deskripsi Skor Hasil Penelitian mengenai Kompensasi

\begin{tabular}{cccc}
\hline Interval & Frekuensi & Persentase & Keterangan \\
\hline $76-84$ & 60 & $21 \%$ & Sangat baik \\
$68-75$ & 100 & $35 \%$ & Baik \\
$60-67$ & 97 & $33 \%$ & Agak baik \\
$52-59$ & 31 & $11 \%$ & Kurang baik \\
Jumlah & 288 & 100,00 & \\
\hline
\end{tabular}

Berdasarkan Tabel 3 di atas, ternyata kompensasi guru SMP Negeri di Kota Semarang tergolong sangat baik dan baik mencapai 56\%, sedangkan guru yang menyatakan agak baik 33\%, dan kurang baik $11 \%$. Hasil analisis deskriptif mengenai kompensasi dapat disajikan dalam bentuk grafik silinder seperti berikut ini.

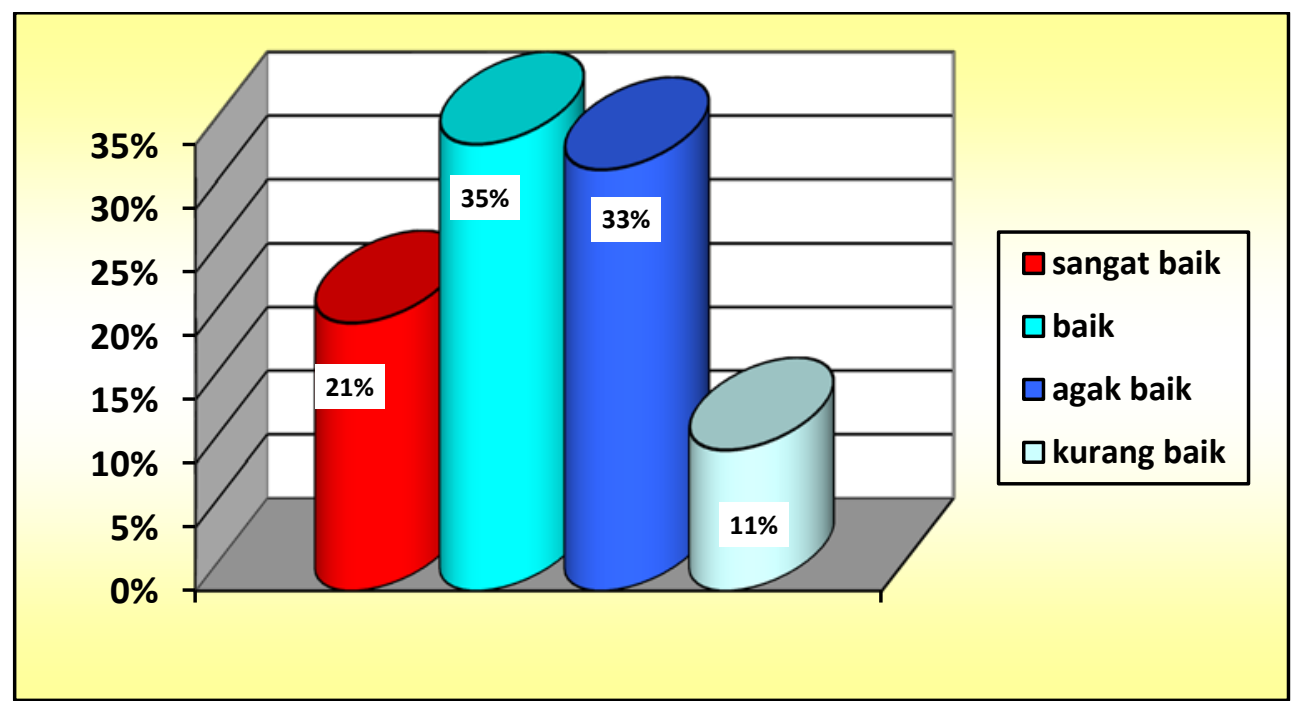

Gambar 2. Grafik Silinder Kompensasi Guru SMP Negeri Kota Semarang

Mengenai tingkat kepuasan kerja guru dari analisis deskriptif diperoleh nilai rata-rata $(X)=61,23$; standar diviasinya (SD) 5,458; skor tertinggi 73, skor terendah 50, dan range 23. Range diperlukan untuk menentukan interval berdasarkan kategori jawaban angket, yaitu 4 kategori. Adapun hasilnya dapat disajikan pada Tabel 4 berikut ini. 
Tabel 4 Deskripsi Kepuasan Kerja Guru

\begin{tabular}{cccl}
\hline Interval & Frekuensi & Persentase & \multicolumn{1}{c}{ Kategori } \\
\hline $68-73$ & 44 & $15 \%$ & Sangat puas \\
$62-67$ & 100 & $35 \%$ & Puas \\
$56-61$ & 101 & $35 \%$ & Agak puas \\
$50-55$ & 43 & $15 \%$ & Kurang puas \\
\hline Jumlah & 288 & 100,00 & \\
\hline
\end{tabular}

Dari tabel di atas, dapat disimpulkan bahwa $15 \%$ guru yang menyatakan sangat puas, $35 \%$ menyatakan puas, $35 \%$ menyatakan agak puas, dan hanya $15 \%$ yang menyatakan tidak puas. Hasil analisis deskriptif mengenai tingkat kepuasan kerja guru SMP Negeri di Kota semarang yang menjadi sampel penelitian dapat disajikan dalam bentuk grafik silinder sebagai berikut.

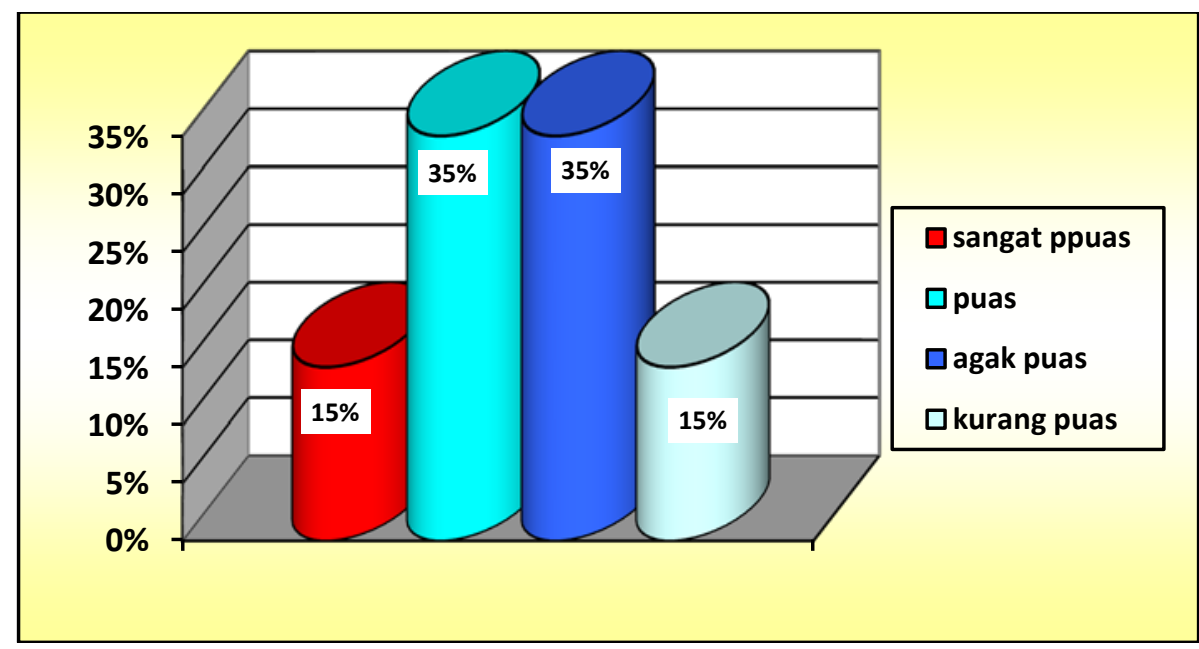

Gambar 3. Grafik Silinder Kepuasan Kerja Guru SMP Negeri Kota Semarang Pengaruh Kepemimpinan Kepala Sekolah dan Kompensasi terhadap Kepuasan Kerja Guru

Hipotesis penelitian yang diuji adalah bahwa "ada pengaruh yang positif dan signifikan kepemimpinan kepala sekolah $\left(\mathrm{X}_{1}\right)$ dan kompensasi $\left(\mathrm{X}_{2}\right)$ terhadap kepuasan kerja guru (Y)". Hasil analisis data dengan SPSS pengaruh kepemimpinan kepala sekolah dan kompensasi terhadap kepuasan kerja guru dapat disajikan secara lengkap pada Tabel 5 berikut ini. 
Tabel 5 Hasil Analisis Pengaruh Kepemimpinan dan Kompensasi terhadap Kepuasan Kerja Guru

Model Summary(b)

\begin{tabular}{llrrr}
\hline Model & R & R Square & $\begin{array}{c}\text { Adjusted R } \\
\text { Square }\end{array}$ & $\begin{array}{l}\text { Std. Error of } \\
\text { the Estimate }\end{array}$ \\
\hline 1 & $.698(\mathrm{a})$ & .488 & .484 & 3.921 \\
\hline
\end{tabular}

a Predictors: (Constant), KOMPEN, KEPEMIMIPINAN

b Dependent Variable: KEPUAS

ANOVA(b)

\begin{tabular}{llrrrrl}
\hline Model & & Sum of Squares & \multicolumn{1}{c}{ Df } & Mean Square & \multicolumn{1}{c}{ F } & \multicolumn{1}{l}{ Sig. } \\
\hline 1 & Regression & 4169.540 & 2 & 2084.770 & 135.612 & $.000(\mathrm{a})$ \\
& Residual & 4381.335 & 285 & 15.373 & & \\
& Total & 8550.875 & 287 & & & \\
\hline
\end{tabular}

a Predictors: (Constant), KOMPEN, KEPEMIMPINAN

b Dependent Variable: KEPUAS

Coefficients(a)

\begin{tabular}{|c|c|c|c|c|c|c|c|}
\hline \multirow[b]{2}{*}{ Model } & \multicolumn{2}{|c|}{$\begin{array}{l}\text { Unstandardized } \\
\text { Coefficients }\end{array}$} & $\begin{array}{l}\text { Standardized } \\
\text { Coefficients }\end{array}$ & \multirow[t]{2}{*}{$\mathrm{T}$} & \multirow[t]{2}{*}{ Sig. } & \multicolumn{2}{|c|}{$\begin{array}{c}\text { Collinearity } \\
\text { Statistics }\end{array}$} \\
\hline & B & $\begin{array}{l}\text { Std. } \\
\text { Error }\end{array}$ & Beta & & & Tolerance & VIF \\
\hline 1 (Constant) & 21.004 & 2.519 & & 8.338 & .000 & & \\
\hline KEPEMIM & .435 & .043 & .544 & 10.197 & .000 & .632 & 1.581 \\
\hline KOMPEN & .170 & .041 & .219 & 4.102 & .000 & .632 & 1.581 \\
\hline
\end{tabular}

a Dependent Variable: KEPUAS

Dari tabel Model Summary(b) di atas, terlihat bahwa $R$ Square $=0,488$. Angka ini menunjukkan besarnya pengaruh kepemimpinan kepala sekolah dan kompensasi guru terhadap kepuasan kerja guru $48,8 \%$. Dengan demikian, ada faktor lain di luar kepemimpinan dan kompensasi sebesar $100 \%-48,8 \%=51,2 \%$. Pengaruh kepemimpinan dan kompensasi terhadap kepuasan kerja guru sangat signifikan. Hal ini dapat dilihat dari nilai $F$ sebesar 135,612 pada taraf signifikansi 0,000.

Besarnya kontribusi kepemimpinan kepala sekolah dan kompensasi ter- hadap kepuasan kerja guru dapat dilihat dari nilai yang ada pada kolom $B$ di bawah Unstandardized Coeficients. Di bawah kolom $B$ nilai Constant $=21,004$, kepemimpinan $=0,435$, dan kompensasi $=0,170$. Dari angka ini dapat dibuat persamaan regresi $\mathrm{Y}=21,004+0,435 \mathrm{X}_{1}$ $+0,170 X_{2}$.

Dari hasil analisis data dapat disimpulkan bahwa ada pengaruh yang positif dan signifikan kepemimpinan kepala sekolah dan kompensasi terhadap kepuasan kerja guru. Kepemimpinan kepala sekolah memberikan pengaruh yang lebih kuat atau lebih besar 
terhadap kepuasan kerja guru jika dibandingkan dengan kompensasi.

\section{PEMBAHASAN}

Keberhasilan kepala sekolah dalam memimpin tidak lepas dari pengalaman kerja sebagai guru, latar belakang pendidikan, pangkat dan golongan. Pengangkatan kepala sekolah selama ini melalui seleksi yang cukup ketat dengan memperhitungkan berbagai aspek, baik dari segi profesionalisme, senioritas, masa kerja, ijazah yang dimiliki, kualitas melalui seleksi, mau pun aspek kepemimpinan. Hal ini tentu akan berpengaruh pada kemampuan para kepala sekolah dalam keberhasilan memimpin sekolah.

Para guru ternyata berbeda pendapat mengenai kompensasi yang mereka terima, namun mayoritas guru yang menjadi sampel penelitian menyatakan bahwa kompensasi yang mereka terima sudah baik. Hal ini wajar karena kompensasi dalam penelitian ini sifatnya sangat umum, dalam arti tidak hanya kompensasi yang bersifat material namun juga yang bersifat nonmaterial. Tentunya akan berbeda jika secara spesifik kompensasi dalam bentuk imbalan uang baik gaji maupun honor/upah. Kecuali itu faktor budaya Jawa juga ikut berperan dalam mewarnai guru terhadap kompensasi yang diterima. Orang Jawa, dalam hal ini para guru SMP Negeri di Semarang memiliki budaya yang sangat dijunjung tinggi yaitu "nrima ing pandum" dan "lila legawa". Artinya, berapa dan apapun imbalan yang diberikan pada para guru akan diterima dengan tulus dan ikhlas, karena orang Jawa berkeyakinan bahwa nrima ing pandum merupakan ujud dari pengamalan rasa syukur pada Allah SWT dan jika hal itu disyukuri maka Allah akan menambah nikmat tersebut lebih banyak lagi. Hal ini sesuai dengan janji Allah SWT dalam Al Qur'an Surat Ibrahim ayat (7) yang artinya, "Jikalau kau mendapat nikmat dari Allah, maka bersyukurlah pasti Allah akan menambah nikmat tersebut lebih banyak lagi, namun jika kamu kufur (mengingkari) nikmat tersebut, maka Allah akan memberikan azab yang lebih pedih".

Kepuasan kerja seseorang (termasuk dalam hal ini guru) dipengaruhi oleh banyak faktor, terutama faktor kompensasi (faktor kesejahteraan baik kesejahteraan lahir mau pun batin yang diterima dari tempat mereka bekerja).

Tingkat kepuasan kerja bagi para guru SMP Negeri di Kota Semarang $50 \%$ merasa sangat puas dan puas. Hal ini juga tidak terlepas dari Budaya Jawa yang berpegang teguh pada prinsip hormat dan prinsip rukun, tidak mau konflik. Karena itu, para guru merasa puas terhadap kepemimpinan mereka maupun kompensasi yang mereka terima.

Dari hasil analisis data diketahui bahwa ada pengaruh yang positif dan signifikan kepemimpinan kepala sekolah dan kompensasi terhadap kepuasan kerja guru. Pengaruh kepemimpinan kepala sekolah terhadap kepuasan kerja guru lebih besar jika dibandingkan dengan kompensasi yang diterima dan dirasakan oleh para guru.

Hasil tersebut di atas logis karena kepala sekolah mampu menjalankan dua fungsi pokok, yaitu: (1) fungsi yang berkenaan dengan tujuan yang hendak 
dicapai; dan (2) fungsi yang berkenaan dengan pemeliharaan kelompok.

Fungsi-fungsi yang berkenaan dengan tujuan yang hendak dicapai di antaranya adalah: (1) merumuskan dan memikirkan para anggota/bawahan/ guru, sehingga mereka menyadari peran masing-masing di dalam mewujudkan tujuan; (2) memberi motivasi/dorongan kepada guru-guru untuk dapat menganalisis situasi sehingga dapat secara optimal mengkreasi kemampuannya demi tercapai hasil yang maksimal; (3) membantu guru-guru memperoleh informasi yang diperlukan bagi pertimbangan pertimbangan yang sehat; dan (4) menumbuhkan kepercayaan dengan jalan melaksanakan delegasi tanggung jawab kepada para guru sesuai dengan kemampuan masing-masing.

Fungsi yang berkenaan dengan pemeliharaan kelompok (fungsional) antara lain: (1) memupuk kerjasama di dalam kelompok dan semangat gotongroyong di dalam mewujudkan tujuan bersama; (2) mengupayakan lingkungan kerja yang menyenangkan demi terciptanya kenyamanan kerja; dan (3) memanfaatkan kelebihan-kelebihan yang ada pada pimpinan maupun teman sejawat untuk kepentingan pencapaian tujuan.

Seperti dikemukakan oleh Indrafachrudi \& Tahalele (1995:28) bahwa dewasa ini macam kepemimpinan yang dianggap baik adalah kepemimpinan demokratis. Semua guru di sekolah bekerja untuk mencapai tujuan bersama. Semua putusan diambil melalui musyawarah dan mufakat serta harus ditaati. Pemimpin menghormati dan meng- hargai pendapat tiap-tiap guru. Pemimpin memberi kesempatan kepada guruguru untuk mengembangkan inisiatif dan daya kreatifnya. Pemimpin mendorong guru-guru dalam hal mengembangkan keterampilannya bertalian dengan usaha-usaha mereka untuk mencobakan suatu metode yang baru, yang akan mendatangkan manfaat bagi perkembangan pendidikan dan pengajaran di sekolah.

Pemimpin demokratis tidak melaksanakan tugasnya sendiri. Ia bersifat bijaksana di dalam pembagian pekerjaan dan tanggung jawab. Dapat dikatakan bahwa, tanggung jawab terletak pada pundak dewan guru seluruhnya, termasuk pemimpin sekolah. Ia bersifat ramah dan selalu bersedia menolong bawahannya dengan memberi nasihat, anjuran, serta petunjuk, jika dibutuhkan. Ia menginginkan supaya guru-gurunya maju dan berusaha mencapai kesuksesan dalam usaha mereka masing-masing. Di dalam kepemimpinannya ia berusaha supaya bawahannya kelak dapat menjalankan tugasnya sebagai pemimpin. Banyak perhatian yang dicurahkan kepada tugas pendidikan dan pengajaran. Acara rapat dewan guru ditetapkan bersama guru. Rapat tersebut dilaksankan secara teratur dan tidak makan banyak waktu. Ia dapat membagi waktu untuk rapat secara ekonomis. Kedisiplinan tampak sekali di dalamnya. Kepala sekolah lebih mengutamakan kepentingan guru daripada kepentingan sendiri. Di bawah kepemimpinannya, guru-guru bekerja dengan suka cita untuk memajukan pendidikan di sekolah. Semua pekerjaan dilaksana- 
kan sesuai dengan rencana yang telah disepakati bersama. Akhirnya, terciptalah suasana kekelurgaan yang sehat dan menyenangkan. Pemimpin sekolah dianggap sebagai seorang bapak, saudara, atau kakak yang dapat menempatkan diri sesuai dengan kondisi dan keadaan lingkungannya (Indrafachrudi \& Tahalele, 1995:29).

Jenis kepemimpinan yang terakhir inilah yang menjadi tolok ukur kebaikan kepemimpinan atau dapat dikatakan kepemimpinan yang ideal. Dengan demikian, apa yang disebut sebagai kepemimpinan yang baik atau buruk pada penelitian ini mengacu pada apakah kepemimpinan itu bercorak demokratis atau tidak.

Pendapat yang berkaitan dengan hasil penelitian ini antara lain dikemukakan oleh Fatah (1996) bahwa faktorfaktor yang mempengaruhi pimpinan dan bawahan secara timbal balik antara lain harapan dan perilaku yang ditampilkan pimpinan dalam membentuk persahabatan dan kerjasama dalam organisasi. Pendapat tersebut menegaskan adanya saling ketergantungan antara pimpinan dan bawahan dalam mencapai tujuan organisasi. Oleh karena itu, diperlukan kerjasama dan saling pengertian.

Penelitian yang dilakukan Hamid (2004) juga telah membuktikan bahwa terdapat hubungan yang positif dan signifikan antara gaya kepemimpinan kepala sekolah dan motivasi kerja dengan kinerja guru. Begitu juga penelitian Suwanto (2004) telah terbukti bahwa pengambilan keputusan partisipatif oleh kepala sekolah mempengaruhi motivasi kerja guru. Nurtain
(1997) juga menegaskan bahwa peranan kepala sekolah pada gaya partisipatif adalah memberikan kemudahan dan mengkomunikasikan berbagai hal yang perlu mendapat perhatian guru.

Pengaruh variabel kompensasi terhadap kepuasan kerja guru menunjukkan bahwa kompensasi yang diterima dan dirasakan oleh para guru memberi pengaruh yang positif dan signifikan terhadap kepuasan kerja guru. Hasil ini mengandung makna bahwa kepuasan kerja guru yang tinggi tidak lepas dari peran kompensasi yang diterima oleh para guru. Dalam hal ini, Handoko (1997:46) menyatakan bahwa pemberian kompensasi merupakan faktor yang penting untuk meningkatkan kepuasan kerja karyawan dalam sebuah organisasi. Hasil penelitian Dworkin (1990) membuktikan bahwa dalam bentuk finansial, khususnya gaji yang tidak memadai dapat menjadi salah satu stressor kerja guru, dan hal ini menempati urutan pertama di antara sejumlah stressor guru. Namun, hasil penelitian Arismunandar (1997) menemukan bahwa potongan gaji merupakan faktor stres yang paling dominan, sedangkan "gaji yang tidak memadai" menempati peringkat ke-10 sebagai sumber stres.

Kepala sekolah yang cerdas tentu akan berusaha keras untuk meningkatkan kinerja guru melalui peningkatan kompensasi, baik bersifat material maupun nonmaterial sehingga bisa meningkatkan kesejahteraan guru, baik secara lahir mau pun batin. Hal ini wajar karena tujuan utama setiap orang bekerja adalah ingin mencari kesejahteraan, baik untuk dirinya sendiri maupun untuk keluarganya. Jika diadakan 
penelitian lebih lanjut mengenai motivasi utama untuk menjadi guru PNS dapat diduga karena mereka ingin mendapatkan pekerjaan yang dapat menghasilkan kompensasi untuk menyejahterakan diri ataupun keluarganya, atau mereka terpaksa menjadi guru kemungkinan besar karena tidak mendapatkan jenis pekerjaan lain yang lebih baik. Ini semua baru praduga, untuk membuktikan kebenarannya perlu penelitian tersendiri.

\section{PENUTUP}

\section{Kesimpulan}

Dari hasil analisis deskriptif dapat disimpulkan bahwa: (1) kepemimpinan kepala sekolah di SMP Negeri Kota Semarang pada kategori sangat baik $24 \%$ dan baik $36 \%$, sedangkan yang agak baik $31 \%$, dan kurang baik 9\%; (2) kompensasi para guru SMP Negeri di Kota Semarang tergolong sangat baik dan baik mencapai $56 \%$, sedangkan yang menyatakan agak baik 33\%, dan kurang baik 11\%; dan (3) tingkat kepuasan para guru terhadap kompensasi dan kepemimpinan kepala sekolah adalah $15 \%$ guru menyatakan sangat puas, $35 \%$ menyatakan puas, $35 \%$ menyatakan agak puas, dan hanya 15\% yang menyatakan tidak puas.

Dari hasil analisis regresi ganda dapat disimpulkan bahwa ada pengaruh yang positif dan signifikan kepemimpinan kepala sekolah dan kompensasi terhadap kepuasan kerja guru. Kepemimpinan kepala sekolah memberikan pengaruh yang lebih kuat atau lebih besar terhadap kepuasan kerja guru jika dibandingkan dengan kompensasi.

\section{Saran}

Mengingat kepemimpinan kepala sekolah berpengaruh secara positif dan signifikan terhadap kepuasan kerja guru, maka kemampuan kepala sekolah dalam memimpin perlu terus ditingkatkan dan dikembangkan melalui berbagai kegiatan seperti pelatihan, seminar, diskusi, sarasehan, workshop, dan sebaginya. Dalam menerapkan gaya kepemimpinan, kepala sekolah perlu mengetahui tingkat kematangan masingmasing guru sehingga gaya kepemimpinan yang diterapkan benarbenar efektif dalam arti sesuai dengan kemampuan dan kemauan guru dalam menerima tanggung jawab untuk melaksanakan tugas.

Mengingat kompensasi juga berpengaruh terhadap kepuasan kerja guru, maka perlu diusahakan secara optimal baik yang menyangkut kesejahteraan lahir berupa material termasuk di dalamnya gaji dan honor. Untuk itu, upaya pemenuhan anggaran pendidikan sebesar $20 \%$ dari APBD sebagaimana diamanatkan oleh Undang-Undang Dasar 1945 dan Undang-Undang Nomor 20 Tahun 2003 tentang Sistem Pendidikan Nasional perlu direalisasi. Kecuali itu, juga kesejahteraan batin yang menyangkut kenyamanan dan keamanan dalam bekerja, penghargaan terhadap prestasi kerja paling tidak dengan ungkapan-ungkapan yang dapat membuat guru menjadi lebih bersemangat dalam bekerja, promosi kenaikan pangkat/jabatan, hubungan kerja dan komunikasi yang harmonis, khususnya antara kepala sekolah dengan guru dan sesama guru, dan sebagainya. 
Bagi peneliti yang lain, disarankan: (1) agar mengadakan penelitian lanjutan dengan pendekatan kualitatif sehingga akan dapat digali lebih mendalam hal-hal yang berkaitan dengan kepemimpinan kepala sekolah dalam menjamin dan meningkatkan kepuasan kerja guru; (2) untuk melakukan penelitian yang serupa (kuantitatif) dengan melibatkan variabel lainnya yang belum pernah diteliti, misalnya berkaitan dengan sarana prasarana, iklim kerja, dan sebagainya.

\section{UCAPAN TERIMA KASIH}

Penelitian ini tidak lepas dari bantuan berbagai pihak. Karena itu lewat kesempatan ini saya sampaikan ucapan terima kasih kepada Prof. Dr. H. Madyo Ekosusilo, M.Pd., dosen Pascasarjana Universitas Negeri Semarang yang telah berkenan membimbing saya dalam menyelesaikan penelitian ini. Terima kasih juga saya sampaikan pada Kepala Dinas Pendidikan Kota Semarang, para Kepala SMP Negeri se Kota Semarang, dan para guru SMP Negeri se-Kota Semarang yang telah bersedia untuk menjadi responden dalam penelitian ini. Terima kasih juga saya sampaikan kepada Redaktur Jurnal Cakrawala Pendidikan Universitas Negeri Yogyakarta yang telah berkenan menerbitkan artikel hasil penelitian ini.

\section{DAFTAR PUSTAKA}

Arismunandar. 1997. Hubungan Karakteristik Individu dan Karakteristik Lingkungan dengan Stres Kerja Guru di Sulawesi Selatan. Disertasi tidak diterbitkan. Malang: Program Pascasarjana IKIP Malang.
Dworkin, A.G. 1990. "Stress and Illness Behavior Among Urban Public School Teacher". New York: Educational Administration Quarterly, 26 (1), 60-72.

Fatah, N. 1996. Landasan Manajemen Pendidikan. Bandung: Remaja Rosdakarya.

Gibson,J.L., Invancevich,J.M.\& Donnelly, Jr. J. H. 1996 Organisasi: Perilaku, Struktur dan Proses. (Edisi Kedelapan). Alih bahasa: Nunuk Ardiani. Jakarta: Binarupa Aksara.

Hadi, S. 1994. Analisis Regresi. Yogyakarta: Andi Offset.

Hamid, A. 2004. Hubungan Gaya Kepemimpinan Kepala Sekolah dan Motivasi Kerja dengan Kinerja Guru SMU Negeri di Kabupaten Kudus. Tesis tidak diterbitkan. Semarang: Program Studi Manajemen Pendidikan, Program Pascasarjana Universitas Negeri Semarang.

Handoko, T. 1997. Manajemen Personalia dan Sumber Daya Manusia. Yogyakarta: BPFE.

Indrafachrudi, S. \& Tahalele, J.F. 1995. Mengantar Bagaimana Memimpin Sekolah yang Baik. Jakarta: Ghalia Indonesia.

Kasidi. 2003. Hubungan antara Kepuasan Kerja dengan Motivasi Kerja Ditinjau dari Jenis Kelamin pada Pegawai Dinas Pendapatan Daerah 
(DIPENDA) Kabupten Dati II Sukoharjo. Tesis tidak diterbitkan. Surakarta: Program Pascasarjana Universitas Muhammadiyah.

Maslow, Abraham, H. 1994. Motivasi dan Kepribadian. Terjemahan Nurul Iman. Jakarta: PT Pustaka Binawan Pressindo.

Nurtain. 1989. Supervisi Pengajaran (Teori dan Praktek). Jakarta: Depdikbud Dirjen Dikti-P2LPTK.

Robbins, S.P. 1995. Organizational Bahavior (5th..ED.). Englewood Cliffs, New Jersey: Prentice Hall, Inc.

Sumadi. 2006. Hubungan Kepemimpinan, Lingkungan Kerja dengan Kepuasan Kerja pada SMA Negeri I Wonogiri. Tesis tidak diterbitkan. Surakarta: Prgram Pascasarjana Universitas Muhammadiyah.
Supardi. 1993. Hubungan Kepemimpinan, Motivasi dan Lingkungan Kerja terhadap Karier Jabatan Akademik Dosen PTS Kopertis Wilayah V DIY. Yogyakarta: Universitas Islam Indonesia, Lembaga Penelitian.

Surya, M. 2000. “Aspirasi Peningkatan Kemampuan Profesional dan Kesejahteraan Guru". Jurnal Pendidikan dan Kebudayaan. Jakarta: Balitbang Depdiknas. Hal 1-12.

Suwanto. 2004. Kontribusi Pengambilan Keputusan Kepala Sekolah dan Motivasi Kerja Guru terhadap Keefektifan Pelaksanaan Program SMP Negeri di Kabupaten Pati. Tesis tidak diterbitkan. Semarang: Program Pascasarjana Universitas Negeri Semarang. 